\title{
Variations on Crisis Management - Through Examples from Hungary after the Change of Regime
}

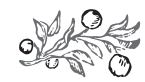

Summary

The samplings included in this study provide insight into the major crisis management measures applied during the more than three-decades of market economy construction that replaced the socialist planned economy system, eroded from the late 1980's. Due to space constraints, the author merely tackles the 1995 economic policy adjustment package, the 2006 autumn adjustment of the convergence trajectory, and the main elements of the comprehensive public finance reform after 2010, and makes reference to the methodology of dealing with the pandemic crisis "unfolding" from the spring of 2020. In addition to public finance measures, the paper also seeks to account for social impacts. This study basically compares the restraint on solvent demand, favoured by the International Monetary Fund and by the World Bank, with the Keynesian economy boosting measures, through the evaluation of the Hungarian practice, which has followed these patterns, and concludes that in times of crisis the expansion of solvent demand by instruments available for the government and for the central bank is the more efficient solution, especially in an emerging Central European market economy.

Journal of Economic Literature (JEL) codes: B52, E42, G01, G28, H31, H63, P41, P43 Keywords: market economy transition, crisis management, austerity, increasing solvent demand, COVID-19, Hungary

Prof Dr Csaba Lentner, Full Professor, National University of Public Service, Budapest and Károli Gáspár University of the Reformed Church, Budapest (Lentner.Csaba@uni-nke.hu). 
Csaba Lentner: Variations on Crisis Management - Through Examples...

\section{INTRODUCTION}

Although the socialist planned economy implemented in Hungary (for more details of the characteristics see Csaba, 2019) underwent numerous attempts at innovation, and significantly differed from the bigoted practice seen in the Soviet Union, the German Democratic Republic, Romania and other "hard-line" countries, from the middle of the 1970 's it showed signs of exhaustion and crisis. The years 1955-1956, and then the socalled New Economic Mechanism adopted in 1968, were decisive in shaping the Hungarian model, imbued with market elements. However, as the reforms could not affect the essence of planned economy, i.e. the predominance of state and co-operative property and the essence of the state economy based on central planning, the limited (enforceable) market elements and the development of more efficient financial interests only generated temporary effects and in a way that the essence of the system practically remained unchanged. For this reason, decline was inevitable in the system as financial disinterest became endemic. However, the economic transformation launched from the late 1980's, i.e. even in the last years of the Hungarian Socialist Workers' Party, lacked a strategy adapted to the country's conditions; the "mere" goal was the soonest possible breakdown of the inoperable social large industry and agriculture. In a different perspective (in stronger but more expressive terms), "getting rid" of the lossmaking largescale industry and agriculture and "passing on" state and political responsibility. An important factor influencing change in the Hungarian regime was public debt, which had increased to USD 21 billion since the 1970's, creating massive base dependence in the course of developing a market economy, and moreover, indebtedness continued to increase. In order to compensate for this chronic shortage of cash, working capital and competitive production, the capacities "dormant" in Western Europe and North America played a countervailing role, relocating to the post-planned economy region, including Hungary. However, due to the weak bargaining position and poor capitalisation of the Hungarian government, the relocated international companies and banks were capable of performing significant profit repatriation. This was underpinned by the relatively cheap but still acceptable skilled labour force in Hungary, the significant state and local government tax reliefs and, what is more, grants provided in support of relocation. Furthermore, the rapid loss of production at and the weakening of state-owned industrial and commercial companies (Tungsram, Rába Wagon and Machine Factory, Csepel Works, and the Ózd Metallurgical Works) in the both the domestic and the foreign markets they had previously supplied "channelled" demand towards foreign companies newly established in Hungary. In addition to privatising companies and means of production, and relocating them to Hungary, international companies also acquired their markets. Thus, an optimum environment was created for operation and profit maximization by these international companies both in terms of input resources and in their output (outcome) channels. However, the economic regulatory system applicable to the production structure and ownership conditions that newly emerged in the late 1980 's provided capital to new companies in such a way as that the central budget and the society were under-positioned, both during privatisation and assets, and in terms 
Civic Review · Vol. 16, Special Issue, 2020

of financial stability. Right at the time of the change of political regime, when the elements of the planned economy system had no longer been functioning and the regulatory environment of the market economy system was still in its infancy (approx. up to 1995), a "transformational crisis" evolved, as coined by economist János Kornai (2016). To address this, the first economic policy adjustment package was launched in 1995. As the Hungarian society had been socialised to paternalistic conditions for decades, it was unprotected and unprepared for these devastating effects, as it was for other crisis management packages based on austerity actions applied to households.

\section{OUTLINE OF THE GRISIS MANAgEMENT MEASURES TAKEN TO REDUCE SOLVENT DEMAND: ECONOMIC STABILISATION IN 1995 AND CONVERGENGE PATH ADJUSTMENT IN 2006}

By early 1995, the overspending fiscal policy and the poorly organised economic activity posed the risk of insolvency, exacerbated by the effects of the international debt crisis started in Mexico and feeding through to Hungary, which made it particularly difficult to finance the growing public debt. The unfavourable developments compelled the Hungarian economic leadership to perform a significant intervention, which was manifest in both the fiscal and monetary line. The budget was cut by about HUF 170 billion. " "The package had two main elements: on the one hand, it aimed to improve the external balance, and on the other hand, to reduce the budget deficit. On the one hand, the national currency was devalued by 9 per cent, and matters were made worse by the introduction of an 8 per cent customs tariff surcharge, which was practically devaluation. Next came a pre-announced fixed rate sliding devaluation system" (Petschnig, 1996, p. 252). The heaviest "extension" of the restriction reaching society was in the form of withdrawals in the social, cultural, housing finance and educational fields. In 1995, in order to (also) improve the goals of financial balance, privatisation, including more precisely, actions to obtain privatisation proceeds began in the energy and financial sectors. As a result of consolidation, wages fell by 12 per cent in 1995, however, it is "true" that - as a result of a more stable fiscal position - working capital, including greenfield investments, in the amount of about USD 4.5 billion, representing 9 per cent of GDP, flowed into the country. In 1995, therefore, a financial adjustment was made which, although it brought about temporary macro-economic improvement, was paid by the population, more specifically, the wage earners and pensioners.

After the turn of the millennium, the budget deficit stabilised at a high level again, mainly due to reasons related to the fact that budget expenditures (especially wage increases) were not covered by sufficient resources. The fiscal policy eased after $2002 \mathrm{had}$ shown a deficit exceeding 9 per cent by the end of 2002, and we moved further and further away from the European fiscal criteria, and this coupled with the persistently high deficits brought Hungary under the excessive deficit procedure of the European Union right from 2004, the year when Hungary became a full member of the European Union. In the autumn of 2006, another convergence path adjustment package, marked by the name of former Prime Minister Ferenc Gyurcsány, was intended to curb the rapidly ris- 
Csaba Lentner: Variations on Crisis Management - Through Examples...

ing budget deficit. The crisis management package, designed to apply fiscal restraints but leaving structural elements unchanged, "weakened" due to the close results of the 2006 parliamentary elections, and its convincing political support gradually decreased.

Each of the two fiscal stabilisation packages resulted in cuts in welfare spending and focused on addressing budgetary and current payment problems. In a comparison of the similarities, it is worth highlighting that from 1993, and then from the end of 2005, the Hungarian economy was on the verge of bankruptcy, as both the current account and the budget deficit were critical. However, the difference between the two packages is that in 2004 Hungary acceded to European Union, and so it became close to bankruptcy despite the European institutional system and regulatory requirements. Inflation played an important role in the 1995 package, hallmarked by the former Minister of Finance Lajos Bokros, as the weakening of the exchange rate and depreciation of the national currency caused by the effect of the tariff surcharge helped to curb incomes. However, in 2006 boosting inflation could no longer be a means of adjustment, as another disinflation would have been significantly less credible and thus much more costly than ten years earlier. The 1995 package sought to avoid GDP decline associated with a decline in domestic demand by a one-off and then continuous, pre-announced devaluation of the exchange rate, which made the economy export-driven, helping to increase GDP artificially (and to some extent hypocritically). On the other hand, the 2006 package was less focused on reducing the sacrifice of growth. The fiscal measures included in the Bokros Package were supported by massive monetary interventions, but in 2006 this was not the case, and moreover, the interest rate increases performed at the latter date curbed investments. The Gyurcsány Package relied on tax increases and the imposition of new types of taxes, narrowed the scope of tax benefits, reduced subsidies, lowered housing loan discounts, and began to reorganise the central public administration. However, adjustments related to increasing revenues and simultaneously reducing expenditures make the business and employee side less interested in implementing consolidation. János Kornai’s (1997) ideas about the 1995 adjustment are thought-provoking: he claimed that each HUF 1 increase in the income during the deficit reduction performed in the mid-1990s was accompanied by a HUF 3 cut in the expenditure, which is a powerful illustration of the adverse social effects. The 1995 stabilisation package produced more tangible results, despite the fact that a significant part of it was found to be unconstitutional by the Constitutional Court, while the measures of the 2006 package were not vetoed by the judiciary, but the planned chopping of free health services and the introduction of contributions payable to higher education were deleted by referendum. The effects of the 2006 measures are also more difficult to assess, as the Hungarian crisis plunged into an even deeper crisis as a result of the international recession processes that began in 2007-2008, which could only be by a USD 25 billion standby credit from the World Bank, the International Monetary Fund and the European Central Bank. It is important to point out that the fiscal policy insufficiency ("fiscal alcoholism") manifested since 2002 was the key factor in the unfolding of the crisis in the Hungarian economy, which was then "only" deepened by the 2007-2008 crisis feeding through 
from the world economic space, and its consequences. The crisis in the international arena merely took the already unsustainable fiscal policy a step further.

The person in charge of the fiscal part in the 1995 scheme justified the need for corrective actions (Bokros, 1997), as in addition to the modest growth potential in real GDP, the current account deficit was 9 and 9.5 per cent in 1993 and 1994, respectively, which had decreased to 3.8 per cent by 1996 as a result of the intervention. At the same dates (1993, 1994 and 1996), the deficit-to-GDP ratio had improved from $4.9 \%$ and $6.2 \%$ to $3.5 \%$, respectively. The ratio of gross government debt to GDP had fallen from 89 to 86.6 , and then to 72.9 per cent by 1996 (Erôs, 2009), ${ }^{2}$ while net external debt had increased from USD 14.9 million to USD 18.9 million and then it had fallen to 12.8 million by 1996. Let us add that while in 1991, GDP declined by 11.9 per cent, in 1992 and 1993 it grew by 3 and 0.6 per cent, respectively, and while in 2009 GDP growth was 2.9 per cent, in both 1995 and 1996 it was 1.5 per cent. The results of the 1995 macro-economic adjustment can therefore be explained, but it had serious social consequences in the form of sacrifices. The person in control of fiscal stabilisation also acknowledged the adverse effects of his measures on income policy, but in the given circumstances he still voted in favour of their necessity, and this decision gave ${ }^{3}$ rise to a professional debate that has continued to this day (see e.g. Matolcsy, 2008; cf. Gyórffy, 2006).

According to András Köves (1995), the 1995 adjustment, similarly to the other shock therapy programmes implemented in the region, did not really take into account the dangers of income reduction, and consequently, the social support needed for economic renewal was not given. Köves also explains that this package was not really meant to stop overconsumption, but rather to radically accelerate the deterioration in the living standards that had anyway taken place to that point. According to his calculations, in 1994 real wages and real incomes were 22-23 and 12-13 per cent lower than in 1989, and in addition, 1.4 million jobs, representing 25 per cent of all the jobs, were lost between 1990 and 1994, exactly as many as created during the four decades of the planned economy. Rudolf Andorka et al. (1994) came to a similar conclusion: real per capita income in 1993 was 12 per cent lower than in 1989. In 1993, consumer prices were 22.5 per cent higher than the previous year and 2.6 times higher than in 1989.

Hungarian small and medium-sized enterprises and the population, which are far less capable of enforcing their interests and shifting charges on others than international companies and banks, were hit home by the quick rise in inflation to 28.2 and 23.6 per cent by 1995 and 1996, respectively, which entailed a significant depreciation in savings. The resumption of privatisation in 1995 also adversely affected the interests of the Hungarian state and its efforts at maximising budget revenues. Note that subsequently, inflation declined: in 1997 and in 1998 it was 18.3 and 14.3 per cent, respectively (for more details see Gyórffy, 2006, p. 247).

A fresh highlight in the process of the regime change predominated by austerities was the economic policy adopted between 1999 and 2002. Its key element was "organised by fiscal measures", targeted through the Széchenyi National Development Plan, and supported by a Hungarian state-owned bank (the Hungarian Development Bank), and implemented by underplanning inflation, and then earmarking and using the arising 
Csaba Lentner: Variations on Crisis Management - Through Examples...

additional budget resources. In other words, economic development took place without sufficient activity of the then central bank, which, despite the effects of unfavourable developments in the world - namely the Asian crisis of 1997-1998 - put the Hungarian economy on a growth path, with nearly three times the average growth rate of the EU. Simultaneously, public debt and inflation declined. Lending relations with the International Monetary Fund practically ceased. ${ }^{4}$ In the years around the turn of the millennium, a period of rapid catching-up could be observed, and Hungary clearly overtook the other Visegrád countries (the Czech Republic, Slovakia and Poland) in terms of GDP per capita (Baksay and Palotai, 2017, pp. 699-700). However, the loose fiscal policy begun in 2002 (following the change of government) led to fiscal imbalances that could not be offset by tightening monetary policy. As a result, Hungary began to drop behind the regional level of development, while the average government deficit in the Visegrád region was only half the figure registered for Hungary, and its level decreased in a trend-like manner compared to the Hungarian processes (Baksay and Palotai, 2017, p. 700), despite the fact that from the middle of the decade an economic boom unfolded in the world (Karsai, 2006). In addition to the fact that the restrictions applied by the central bank proved to be insufficient for offsetting the effects of the loose fiscal policy, based on Leeper's theorem (Leeper, 1991) it could even be proved in detail that neither a monetary policy endeavouring to cut debt by inflation nor one sacrificing growth for price stability was able to cancel this attitude of excessive spending. As a result of poorly organised budgetary processes, labour market problems intensified (Fazekas and Scarle, 2012), and households' attention was drawn to foreign currency loans, which were easier to access and cheaper but carried high-repayment risks (Kovács, 2013; Lentner, 2015), which provided additional financing to offset the economic uncertainty caused by the weakening business environment, and represented an endeavour to escape forint loans, which are inherently more difficult to repay due to their a priori higher interest rates. The growth model maintained by the increasingly indebted public finances and the primary income owning sectors indebted in foreign currency came to a dead end in 2006 (Orbán and Szapáry, 2006), but since the global economic crisis unfolding in 2007-2008 caused a rapid hike in the rates of the external resources denominated in foreign currency and in their interest rates, effective inoperability became obvious and the country needed international help. The intention to adjust the 2006 convergence trajectory was thus focused largely revenues, and this increased taxes on the primary income owners, while simultaneously reducing their incomes, but making little effort at addressing structural deficiencies, it could alleviate problems only temporarily. From 2006 to 2007, the budget deficit to GDP decreased from 9.3 to 5.1 per cent, but due to the budget previously fuelled by overspending and then tightened, and to a decline in the external resources, economic growth dropped from 3.9 to 0.4 per cent, while in the rest of the Visegrád region it was 7 per cent on average over this period. According to the calculations of György Matolcsy, "in the five years between 1998 and 2002, Hungary was the country fastest converging to the EU average in terms of GDP per capita among the new EU Member States in the region, but then in the second five-year cycle between 2003 and 2007 it became the slowest one in integration. In the first five years, we con- 
verged to the EU average by 8.8 per cent, while in the second, the corresponding rate was only by 1.1 per cent". György Matolcsy $(2008$, p. 13) also described that in addition to the slowdown in integration between 2003 and 2007, the advantage convergence that had been created in the previous five years was lost, and he even suggested that the 2003-2007 period had better opportunities in terms of external sources. The evolution of the purchasing power of money did not reflect stable conditions either. According to data by Ernô Huszti (2011, pp. 160-167), ${ }^{5}$ between 1995 and 2002 the purchasing power of the national currency increased by 24.2 per cent (to $75.8 \%$ ), while between 2003 and 2010 (compared to the data of the first term year taken as 100\%) it decreased by 27.3 per cent (to $72.3 \%$, compared to the figure of the first year in the term taken as a base line).

Due to weak macro-economic data and the uncertain and contradictory economic environment, in the midst of international events in the autumn of 2008, which also led to a loss of confidence in finances, most investors withdrew from the government securities market and numerous manufacturing companies switched to reduced reproduction. Of the EUR 19.3 billion requested from the International Monetary Fund, the World Bank and the European Central Bank, EUR 14.3 billion was actually drawn down. Credit demand was excessive, while the amount drawn was used in an unprofessional manner (Lentner, 2013, pp. 268-269). The loan was accompanied by a need for further restrictions on lenders. Thus, instead of boosting fiscal demand, Hungarian crisis management continued with fiscal austerity, i.e. a pro-cyclical method that further worsened the economic downturn. Real GDP fell by 6.6 per cent in 2009 in of the Hungarian economy, which was a record low in the EU, and moreover, the budget deficit increased from 3.6 per cent in 2008 to 4.5 per cent in 2009 and 2010. Under crisis conditions, the additional taxes levied on primary income owners (companies and households) curbed production, thus increasing the deficit by about 1.5 per cent. The crisis also hit the economy of the European Union, which has a key role in the export and capital import trends of the Hungarian economy, and brought to the surface the shortcomings, weaknesses and dysfunctional operation of the institutional system of the Economic and Monetary Union (Losoncz, 2010). In the internationally spread set of crises, central bank policies (for their functioning, see Neményi, 2009; 2011) ${ }^{6}$ and the bans on state aid, which had previously been in conflict with operation of the free market (Staviczky, 2010), were placed in a new context, but as the Hungarian fiscal and monetary authority had been rolling the problems forward, was only able to adopt very little of it, or was only able to enforce these measures with low efficiency (Bolf-Galamb and Kányási, 2010), ${ }^{7}$ especially with regard to the country's near-crash situation, which "unfolded" two years earlier. All this demanded further social sacrifices, and prevented Hungary from substantively joining the international crisis management methods applied right after breakout of the crisis, and could therefore join only years later.

During transition to a market economy, the role of the state in economy management was limited to downsizing its property, "curbing" its regulatory system and "containing" its control mechanisms, and due to the high taxes and the fact that having been socialised for socialism, the society expected paternalism as a non-means-tested right, economy management was ultimately carried on in the form of a "basis-dependent 
Csaba Lentner: Variations on Crisis Management - Through Examples...

planned-economy" kind of policy. The spill-over effects of this bad economic structure to market economy, the "moderation" of the "generous" social welfare system detached from state revenues, the practice of repeated "releases for the sake of political and social peace", and then, the compelled economic focus on foreign direct investment, supported by tax benefits and even budget subsidies, accelerated Hungary's indebtedness. The economic policy, which a priori set out with a "birth defect" (Stumpf, 2014, pp. 18-24) at the time of the change of regime, produced continuous deficit, because the structure of the economy and the applied social policy "predestined" it, and then it responded to the problems that became critical from time to time by imposing additional taxes on the residents with restricted capacity to defend their interests. The interest of primary income owners in reforms and consolidations was thus reduced to the minimum, and moreover, in some cases provoked significant social resistance, at the "end" of which these resident income groups rejected the restrictions-based policy of the government and ultimately also the restrictive government itself. According to Péter Mihályi (2014, p. 903) ("in addition"), the majority of the Hungarian population opposes all kinds of modernisation from the outset, because most of their income is received through state redistribution, which also results from the distorted employment structure. This is because 60 per cent of the adult population is either a public employee or, predominantly, living on public income transfer. Each of the economic adjustments based on austerity measures ended in failure, they did not achieve the desired effect, but the undoubted result of a good two-decade course in building a market economy was the implementation of a peaceful transition and integration into the EU.

\section{RESOLUTION OF THE SYSTEMIC CRISIS AFTER THE CHANGE OF REGIME: THE POST-2OIO PUBLIG FINANGE REFORM}

In the run-up to the 2007-2008 global economic crisis, Hungary was characterised by poorly regulated public finances, flawed and unsustainable fiscal policies, and nontransparent fiscal management, and overspending was financed by external sources. As a result, the business angels who favoured neoliberal principles expected the same neoliberal economic policy from the Hungarian state, which was struggling in a debt trap. This is where they saw the guarantee that Hungary would repay its loans, but this kind of economic policy was unsustainable for Hungary in the long run, as it did not fit the needs and capabilities of the Hungarian productive forces and production conditions. After the turn of the millennium, both government debt and the interest burden rose sharply. Net external debt rose from 16.5 per cent of GDP in 2002 to 28.2 per cent by 2005. The government debt-to-GDP ratio had increased from 54.6 per cent (in 2002) to 64.1 per cent by 2006, and by 2010 it had already exceeded 80 per cent. In this period, Hungary's fiscal deficit was around 7 per cent of GDP. By 2006, the country's operation had become unsustainable, and the 2007-2008 crisis further aggravated the situation. As a result, a reform was required in state operation and public finances (Lentner, 2018). Following the change of government and economic policy in 2010, Hungary no longer received security loans from the World Bank and 
Civic Review · Vol. 16, Special Issue, 2020

from the International Monetary Fund, but the EUR 12.5 billion "requested" from IMF during the 2008 crisis, the EUR 6.5 billion taken from the European Union and the EUR 1 billion loan package from the World Bank were repaid.

After 2010, public finance reforms were introduced in Hungary with the aim to create an efficient public sector, a corporate sector interested in production and investment, and a society interested in income growth. As a result of the public finance reform, the fiscal regulatory environment changed, a number of new legal acts were enacted in the Hungarian legal system, accompanied by the establishment of appropriate and effective state control, and a rules-based fiscal policy became the norm. Hungary's Fundamental Law, which entered into force in 2011, raised the issue of public financial responsibility to a constitutional level. The chapter on public funds contains regulations on the central budget, public debt, national property, transparency, contribution to public finances, the National Bank of Hungary, the Fiscal Council, and the State Audit Office. The key principle of this chapter is balanced, transparent and sustainable fiscal management. In the Fundamental Law the chapter on public finances focuses on the reduction of public debt. Pursuant to Article 36 (4)-(5) of the Fundamental Law, "(4) Parliament may not adopt an Act on the central budget as a result of which state debt would exceed half of the Gross Domestic Product. (5) As long as state debt exceeds half of the Gross Domestic Product, Parliament may only adopt an Act on the central budget which provides for state debt reduction in proportion to the Gross Domestic Product". According to section (6), "Any derogation from the provisions of paragraphs (4) and (5) shall only be allowed during a special legal order and to the extent necessary to mitigate the consequences of the circumstances triggering the special legal order, or, in the event of an enduring and significant national economic recession, to the extent necessary to restore the balance of the national economy".

The fiscal reforms implemented after 2010 include a reduction in taxes on live labour, broadening the family tax credit, increase in the weight of consumption and sales taxes, and tax levied on extra-profit. The reform of the tax system was performed with focus on the reduction of income taxes (personal income tax and corporate income tax), which generated solvent household and corporate income, and the income taxes "removed" from the budget were amply offset by the general sales and excise taxes paid on the increased turnover. In addition to tax reforms, the social security system was also reformed. By the end of 2010, the budget deficit caused by mandatory private pension funds had been widening, as the pension contributions payable to private pension fund members - "by definition" - flowed to private funds, and the current revenues meant to cover public pension expenditures fell sharply, and generated gap had to be closed from public funds. The problem was that private funds only attracted the more well-to-do sections of the population and the relatively well-earning young people starting out on their careers, while they were suitable for considerably fewer, if any, of the lower-income citizens and the elderly right before retirement. As the Hungarian system has traditionally been based on the pay-as-you-go scheme, funding the benefits of pensioners, who make up one third of the country's 10 million citizens, and the future allowances of the next generations of pensioners 
Csaba Lentner: Variations on Crisis Management - Through Examples...

became increasingly hopeless. As a result, the mandatory private pension scheme was abolished and a significant number of members withdrew to the state pension system.

With the entry into force of the Fundamental Law, discipline in and control over public finances became stricter. Following the adoption of the Fundamental Law, Act LXVI of 2011 on the State Audit Office issued was adopted as a cardinal law, which expanded the SAO's audit powers and competences. The purpose of the law is to be able to act more efficiently to protect taxpayers' money and the nation's wealth when they are used. Since then, the SAO has had the right to monitor any use of public funds and assets. The Fundamental Law raised the Fiscal Council among the bodies of constitutional status, thus it became a body supporting the legislative work of the National Assembly, which performs its tasks in compliance with the Fundamental Law and the and other statutory regulations. It participates in drafting the Central Budget Act, and acting as a body to support the legislative activity of the National Assembly, it qualifies the central budget and checks if it gives a true and fair view, and gives its preliminary consent to the approval of the Act on the Central Budget in order to ensure compliance with the so-called public debt rule (Kovács, 2017). After 2010, the efficiency of tax collection improved, which was then facilitated by the adoption of an online invoicing and cash register system, and the launching of the Electronic Public Road Trade Control System.

During this period, Hungary's local government system was transformed and its debt was consolidated (for more details see Lentner and Hegedús, 2019), and the relevant provisions of the Stability Act (Act CXCIV of 2011) and of the Act on National Property (Act CXCVI of 2011) also contributed to the stabilisation of both the central and the local government sub-systems. The enactment of the Stability Act had a significant role in the debt cutting process, and it regulates the Fiscal Council. The Act on National Property contributes to the transparent and responsible management of the national property and to the preservation and protection of national values.

The co-ordination of fiscal and monetary policies was indispensable for economic growth. The monetary breakthrough took place in Hungary in 2013. Since then monetary policy has played a more proactive role in boosting economic growth while simultaneously ensuring price stability. As a result of gradual reduction in the base rate (from 7 to 0.9 per cent by 2016, and in the first step to 0.75 per cent and then to 0.6 per cent in the summer of 2020), private sector financing costs fell and investment and consumption picked up. After 2013, the National Bank of Hungary launched several schemes to strengthen financial stability and boost economic growth. These include the Funding for Growth scheme, similar to the British Funding for Lending or the US QE system, aimed at restarting corporate lending. Between 2013 and 2017, this scheme increased GDP by 2 to 2.5 percentage points (Matolcsy and Palotai, 2019). The phasing out of foreign currency loans was a measure of key significance: the National Bank of Hungary provided HUF 9.7 billion to banks for the conversion of FX loans to HUF loans (Kolozsi et al., 2018). In 2014-2016, the Hungarian state repaid nearly EUR 11 billion as foreign currency debt from forint issues. Central bank schemes and economic improvements also had a positive effect on corporate lending. 
Civic Review · Vol. 16, Special Issue, 2020

Increase in corporate lending by more than 10 per cent in 2017-2018 confirms that companies have confidence in economic growth and closing the economic gap.

The renewal of public finances after 2010 has contributed to a lasting and effective co-operation between the Hungarian state and the economic participants, which provides an opportunity to build a well-governed state (Kolozsi et al., 2018). A strategic change of direction was required, as the Hungarian economy had been characterised by high external indebtedness and internal imbalances. According to a study by György and Veress (2016), the current challenges of the Hungarian economy can be traced back to the erroneous strategic decisions of the past, so the measures taken after 2010 were aimed at addressing these challenges. The main priorities of the Hungarian public finance system have changed, so after 2010, among other things, the transformation of large distribution systems (pension scheme, social security, health care and higher education) and the transformation of the division of labour between the central and local government levels took place. The most important goals of the changes included increasing the room for manoeuvre in economic policy, ensuring transparency and predictability and creating a work-based society, because the more people work, the stronger the society (Schlett, 2017). Hungarian economic policy measures were important after 2010 because the budget adjustment was not accompanied by austerity measures, but by reducing the tax burden and, at the same time, reducing the shadow economy (Varga, 2017).

Thanks to the changes in legislation performed since 2010, the public finance reforms and the proactive central bank policy adopted after 2013, Hungary has embarked on a long-term growth path. The steady growth seen since 2013 has been accompanied by the maintenance of the macro-financial balance and reduction of the vulnerability of the economy (Matolcsy and Palotai, 2019), which, as everywhere in the world, came to a halt and even declined as a result of COVID-19.

As a result of the Hungarian public finance reform, a legal background is provided by the cardinal laws in addition to the Fundamental Law. The new Law on the State Audit Office (Act LXVI of 2011) was the first of the cardinal laws to be adopted. The law, which is in line with international standards, strengthened the independence of the State Audit Office, expanded its audit powers and increased the transparency of audits by clearly disclosing reports. With focus on the public finance system, the responsibilities of the State Audit Office have also become a priority. As a result of the expansion of the audit powers of the State Audit Office, legislation restructured the operation of the body. The act vested the State Audit Office with new responsibilities and powers the organisation is completely free to use in compliance with statutory requirements, their only mandatory task is the preparation of analyses to support the work of the Fiscal Council (Domokos, 2019). With the tightening of the fiscal control environment, the era of non-consequential controls is over.

As a result of the public finance reforms implemented after 2010, Hungary's fiscal positions (deficit and government debt) and the inflation rate improved significantly, along with the external positions, in line with the single-objective fiscal and monetary policy aspirations (Figure 1). 
Csaba Lentner: Variations on Crisis Management - Through Examples...

Figure 1: Government deficit and the net financing position of the national economy

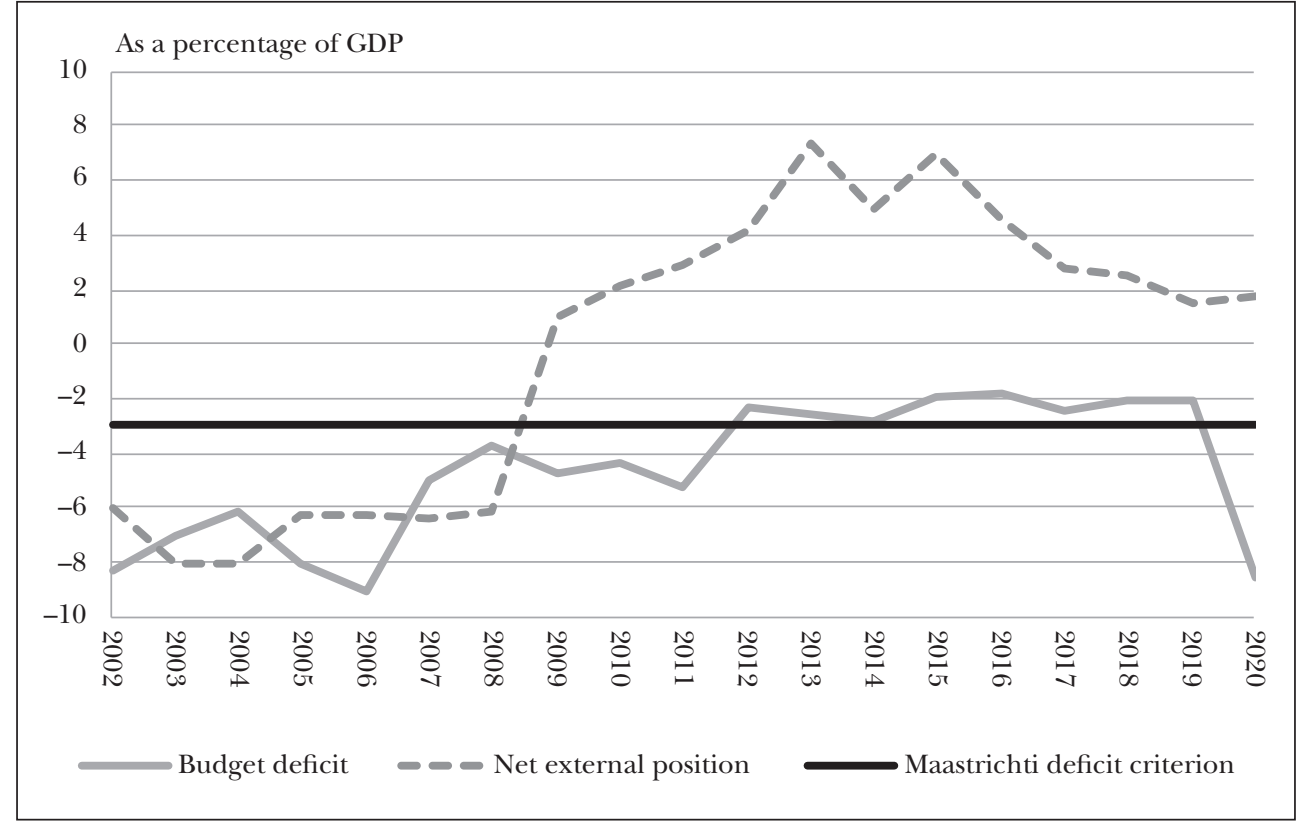

Source: National Bank of Hungary (2020) and Eurostat (2020)

Figure 2: Inflation, 2008-2020

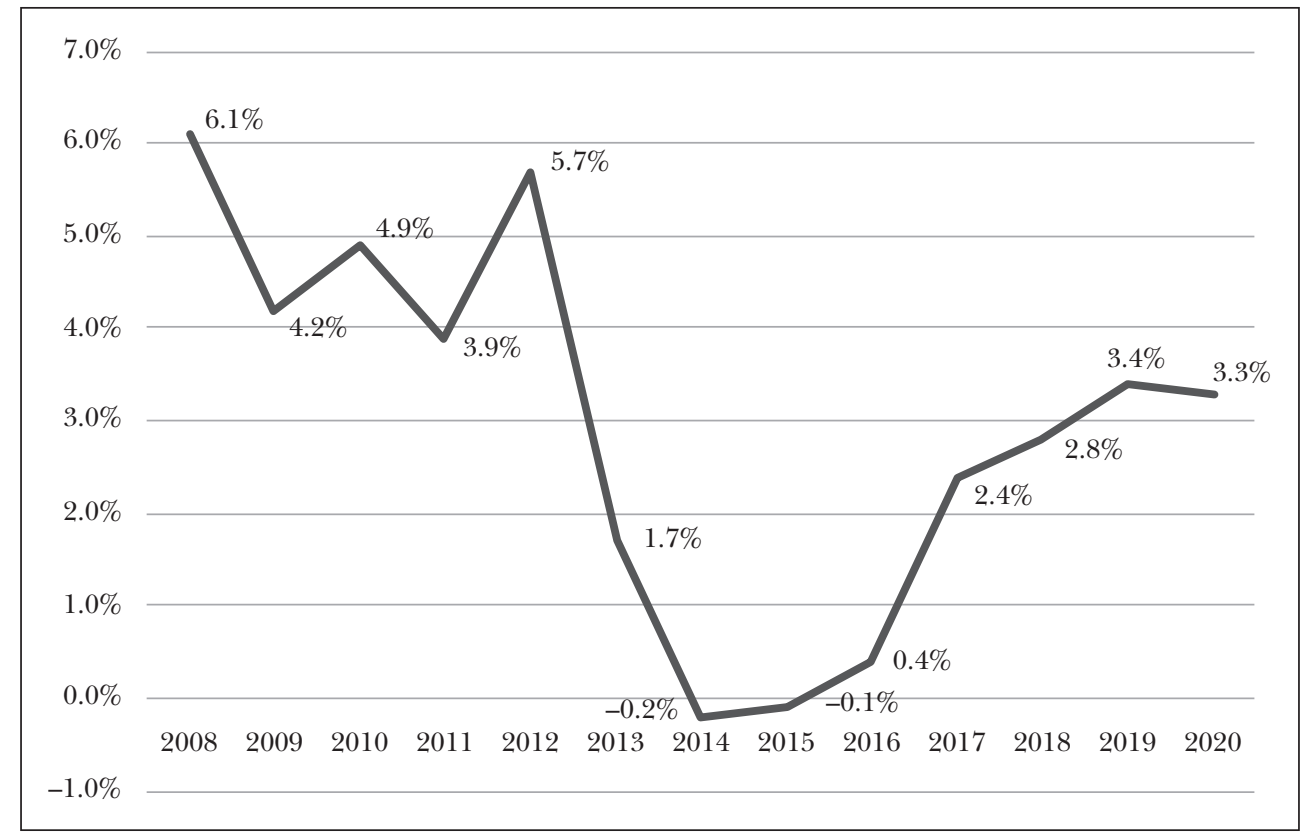

Source: Hungarian Central Statistical Office and National Bank of Hungary (2020) 
Civic Review · Vol. 16, Special Issue, 2020

\section{Crisis MANAgEMENT in THE EVENT OF A SHOCK ATtRibutable TO EXTERNAL FACTORS - Mitigating THE EFFEGTS OF THE COVID- 19 PANDEMIC}

COVID-19, which hit Hungary in the early spring of 2020, caused an economic downturn. The pandemic threat has significantly deterred the workforce from participating in labour market integration. It restrained demand for services in the tertiary sector, and the combined effect was a decrease in production and in GDP. It is important to emphasise that the crisis is not a consequence of the operation of the Hungarian government and the central bank, but clearly a feed-through effect of external factors. The problems hit Hungary at the peak of its growth trajectory built since 2010.

In contrast to the crisis management measures applied in 1995, 2006 and 2008, the government does not focus on imposing additional burdens on the population and on small businesses. It was emphasised that there would be no austerity, no increase in taxes, and no reduction in social benefits, on the contrary. The central bank is trying to mitigate the adverse consequences of the crisis by increasing refinancing loans, encouraging commercial banks to continue lending to companies, lowering the base rate and introducing a repayment moratorium.

According to the government's appropriation for March 2020, the crisis management package amounts to 18-22 per cent of GDP, approximately HUF 11,000 billion. ${ }^{8}$ Efforts are made at finding funds to cover crisis management by increasing budget expenditures, temporarily "easing" the deficit requirements and raising the central bank's refinancing credit line, i.e. by a combination of the fiscal and monetary means of boosting the economy. However, during the reconstruction of the economy returning to a higher than the pre-crisis levels seems reasonable. In other words, during the reorganisation, it is also justified to perform the long-delayed technological renewal and mergers, which will improve the economies of scale in the small and mediumsized enterprise sector. Obviously, the efficiency of the current crisis management could have been further enhanced if, in the period 2013-2019, either a single-digit personal income tax or a further reduced corporate income tax had entered into force. Thus, the solvent demand, investment and consumption demand of both the population and companies would be higher, and consequently, the state would have to pay less corporate support and job-retention subsidies, and the consumption and solvent demand reserve of the population could be higher. Undoubtedly, preparedness for crisis management and the method of managing crises provide a competitive edge at the level of the national economy, but also at the level of companies and households.

In Q2 2020, GDP fell by 13.6 per cent, the volume of industrial production by 25 per cent, the tourism sector by 80 per cent and the hospitality sector by 60 per cent. A similar, although smaller decline is expected for Q3 and Q4 of 2020 and even for H1 2021, and as a result, GDP is likely to decline for 2020 as well as 2021, and this will certainly weaken the fiscal stability of the state. All these further raise the need for a kind of reconstruction with more emphasis on the new challenges of the 21st century 
Csaba Lentner: Variations on Crisis Management - Through Examples...

(for more detail see the paper written by György Matolcsy in this issue), on digitisation, the development of a green economy, transforming consumer and work habits, and the challenges posed by the aging of society. The short- and medium-term economic strategy for the Hungarian national economy provides a safe solution to debt financing simultaneously with improving competitiveness and mitigating the acute impacts of the crisis.

In the next few years, results may hardly be expected without the proactive involvement of the government and the central bank, without influencing the economy. The reorganisation of global value chains, the strengthening of regional positions, the diversification of supplier bases, and increase in the volume of security stocks are to be expected globally. The tectonic plates that make up the world economy will thus be rearranged, and this change requires an efficient response from nation-states, while the role of international institutions is expected to relatively diminish. Concerning our region, internal tensions are expected to intensify within the European Union, the north-south fault lines may increase, and these processes will assign a higher value to the crisis management capacity and method applied in the Hungarian economy, and moreover, the frames of a new development trajectory should be built. The competitiveness of the tax system should reasonably be further increased, funding for public finances needs to be further diversified, and the optimum of internal and external sources should be identified. Although Hungary has achieved historical results in public debt management between 2011 and 2019,9 "restart in the accumulation" of public debt should be expected over the medium term, and thus the emphasis will shift even more to secure financing. During the accelerating reorganisations in the world economy, Hungary needs to climb in the development directions (tectonic plates) that help it to break out of the trap of stagnating at a medium level of development, or to prevent the "embedding" of the consequences of the current crisis for decades. Thus, an even more innovative fiscal policy may provide the chance to avoid "getting stuck". This requires actions similar to those taken under similar crisis conditions in South Korea, Singapore or Finland decades earlier. The digitisation of public services, healthcare reforms and substantial improvements in the quality of higher education can be considered as key areas for real catching up.

\section{Conclusions}

During the application of crisis management methods, it is appropriate to take into account the political, social and legal specificities of the given country. According to Ramady (2010), any economic reform is successful if it is based on the particular country's legal and regulatory framework and ensures an optimum distribution of the resources required for the society. Improvement in both financial and non-financial institutions is indispensable for the efficient use of public funds. According to Diamond (2003), strategic budget planning, refashioning the existing programmes, improvement in the fiscal system and the adoption of a system of accountability and fiscal incentives are indispensable prerequisites for the success of reforms. Running 
the appropriate budgetary institutions is important for the efficient implementation of the fiscal policy (Aidt et al., 2008). Most of the Hungarian crisis management measures of the last thirty years cannot be said to meet all these requirements.

The neoliberal economic reforms favoured by the IMF and the World Bank have failed in post-socialist countries, but especially in Hungary, in recent decades. ${ }^{10} \mathrm{~A}$ balanced budget and a low-inflation environment were acceptable targets, but the road to achievement, i.e. deregulation, privatisation and the neoliberal crisis management method used in their implementation, which further reduced solvent demand, proved to be unsuccessful, especially in the context of rapid and non-transitional liberalisation, as evidenced (among others) by the unfolding of a situation close to Hungary's bankruptcy 1995 and 2006, which further reduced solvent demand. Let us add, however, that both international organisations have learnt from their mistakes and have returned to Keynes' principles, but their goal is still to remain indispensable players in the international financial system even in a multipolar world order. Now they already give countries a wider fiscal leeway, and approve slower spending cuts if it is combined with public investment projects and, through this, economic recovery. A significant feature of the Hungarian public finance reform after 2010, which "pulled the country in crisis out of the pit", was a moderate departure from the normative recipe offered by IMF and the World Bank, i.e. strengthening the role of national property and the state in influencing the economy, broadening economy regulation in contrast to deregulation, the adoption of a tax system more adjusted to the participants' capacity to pay, and, in addition to all these, the National Bank's monetary policy to moderate inflation, and the enforcement of various considerations to boost the economy and ensure financial stability.

In the case of Hungary, however, the 1995 economic stabilisation package based on the crisis management proposals of the international financial institutions, the convergence path corrective actions announced in the autumn of 2006 and the stabilisation measures taken in the autumn of 2008 were essentially limited to addressing the critical and most pressing imbalances, however, curbing solvent demand, investment and imports demanded overall sacrifices to the detriment of growth and social conditions, making them unfeasible and ineffective over the long term. Let us add that the near-bankruptcy situations that unfolded in both 1995 and 2006 resulted from these flawed measures aimed at dismantling the planned economy system without any transition, accelerating deregulation and privatisation, and rapidly reducing the protection of the internal market.

The Keynesian fiscal boosting, which proved successful in dealing with the crisis of 1929-1933, was also favoured by advanced market economies after the 2008 crisis. Hungary, on the other hand, was not in a position, as it did not have the incentive and did not have the "approval" of the European Union to make a move towards boosting demand by increasing the budget deficit during (and embedded in) the 2010 public finance reform. Prior to 2013, no rate cuts had been made or substantial crisis management measures taken by the Hungarian central bank, what is more, the base rate even rose, thus making access to credit more expensive. However, as a result 


\section{Csaba Lentner: Variations on Crisis Management - Through Examples...}

of the wide-ranging tax reform, by 2013 (in 3 years), the fiscal trajectory "smoothed out", and Hungary was released from the excessive deficit procedure of the European Union. The Keynesian tools of economy influencing were put in place by the post2010 government, with proven results at the macro-economic, corporate and retail levels, and favourable experience has shown that the series of responses to the effects of the COVID-19 pandemic, toxic for the economy, should also be built on a Keynesian philosophy of recovery.

\section{Notes}

1 In the spring of 1995, the USD exchange rate was around HUF 110-120.

2 Public debt theoretically has an adverse impact on the pace of economic growth because the economic stakeholders suspect future tax increases behind rising indebtedness. For more details see Erôs, 2009, pp. 324-332).

3 For criticisms of the austerity packages see, among others: Matolcsy, 2008; 2015; cf. Gyôrffy, 2006.

4 For analyses of the improvement of mostly endogenous factors, and of raising internal financing sources for the most part "in our own way - organised by ourselves", and descriptions of the economic policy course, see Matolcsy, 2002 and Lentner, 2020, Chapter 5.

5 Let us add that the inflationary conditions generated, among others, by the high budget deficit compelled monetary policy-makers to take a restrictive (compensatory) approach, which led to the strengthening of the price stability mandate and the inflation targeting system.

6 On capitalised non-standard central bank instruments and the effects of the financial crisis in an international perspective: Neményi, 2011, cf. a description of the Hungarian practice by the same author: Neményi, 2009.

7 The job support options listed in this publication were insignificant to the severity of the problems, although they were announced on the grounds of qualifying the case as most urgent for the granting of state aid under Article 107 (1) of the Treaty on the Functioning of the European Union.

8 For the conversion: At the end of 2020, the exchange rate of the euro fluctuated between HUF 350 and 370 .

9 The ratio of external government debt fell from 66 to 34 per cent, the foreign currency ratio of government debt fell from 50 to 17 per cent, and the overall government debt to GDP fell from 83 to 65 per cent.

10 As, for example, in Chile, Argentina or Greece.

\section{REFERENCES}

Aidt, T.; Dutta, J. and Sena, V. (2008): Governance Regimes, Corruption and Growth: Theory and Evidence. Journal of Comparative Economics, Vol. 36, No. 2, 195-220, https://doi.org/10.1016/j.jce.2007.11.004.

Andorka, R.; Kolosi, T. and Vukovich, Gy. (eds.): Társadalmi riport 1994 [Social report]. Tárki, Budapest.

Baksay, G. and Palotai, D. (2017): Válságkezelés és gazdasági reformok Magyarországon, 2010-2016 [Crisis management and economic reforms in Hungary, 2010-2016]. Közgazdasági Szemle, Vol. 64, No. 7-8, 698-722.

Bokros, L. (1997): Pénzügyi stabilizáció recesszió nélkül [Financial stabilisation without recession]. Európai Fórum, Vol. 7, No. 2, 16-31.

Bolf-Galamb, Zs. and Kányási, Zs. (2010): A pénzügyi és gazdasági válság kapcsán Magyarországon bevezetett munkahelyteremtố és munkahelymegôrzô intézkedések rövid bemutatása [A brief description of the job creation and job retention actions taken in Hungary in relation to the financial and economic crisis]. In: Állami támogatások joga [The law of state subsidies]. Vol. 2, No. 2, 77-88, Ministry of National Development. 
Civic Review · Vol. 16, Special Issue, 2020

Csaba, L. (2019): Post-Communist Systemic Change: Lessons for East Asia. Asian Journal of Peacebuilding, Vol. 7, No. 2, https://doi.org/10.18588/201911.00a103.

Diamond, J. (2003). From Program to Performance Budgeting: The Challenge for Emerging Market Economics. IMF Working Paper, WP/03/169, www.imf.org/external/pubs/ft/wp/2003/wp03169.pdf.

Domokos, L. (2019): Ellenôrzés - a fenntartható jó kormányzás eszköze [Auditing - a tool for the sustainable good governance]. Akadémiai Kiadó, Budapest.

Erôs, A. (2009): Az államadósság-felhalmozás hatása a gazdasági növekedés hosszú távú egyensúlyi értékére [Impacts of accumulating sovereign debt on the long-term equilibrium in economic growth]. In: VII. International Conference. Conference paper, University of Miskolc, 324-332.

Fazekas, K. and Scharle, Á. (eds.) (2012): Nyugdíj, segély, közmunka. A magyar foglalkoztatáspolitika két évtizede, 1990-2010 [Pension, aid and community service. Two decades in Hungarian employment policy, 19902010]. Szakpolitikai Elemzô Intézet - MTA KRTK Közgazdaságtudományi Intézet.

György, L. and Veress, J. (2016). The Hungarian Economic Policy Model After 2010. Public Finance Quarterly, Vol. 61, No. 3, 360-381.

Győrffy, D. (2006): Governance in a Low-Trust Environment: The Difficulties of Fiscal Adjustment in Hungary. Europe-Asia Studies, Vol. 58, No. 2, 239-259, https://doi.org/10.1080/09668130500481410.

Huszti, E. (2011): Egy valuta története. A forint forgalma a stabilizációtól az euró elôszobájáig [The story of a currency. Forint turnover from stabilisation to the staircase to the euro] L'Harmattan Kiadó, Budapest.

Karsai, G. (2006): Ciklus és trend a magyar gazdaságban 1990-2005 között [Cycle and trend in the Hungarian economy between 1990 and 2005]. Közgazdasági Szemle, Vol. 53, No. 6, 509-525.

Kolozsi P. P.; Lentner, Cs. and Parragh, B. (2018): Pillars of a New State Management Model in Hungary: The Renewal of Public Finances as a Precondition of a Lasting and Effective Cooperation Between the Hungarian State and the Economic Actors. Polgári Szemle/Civic Review, Vol. 14, Special Issue, 12-34, https://doi.org/10.24307/psz.2018.0402.

Kornai, J. (1997): Adjustment Without Recession: A Case Study of Hungarian Stabilization. In: Zecchini, S. (ed.): Lessons from the Economic Transition. Kluwer Academic Publisher for the OECD, Dordrecht, London, Boston, 123-152.

Kornai, J. (2016): Még egyszer a „rendszerparadigmáról”. Tisztázás és kiegészítések a posztszocialista régió tapasztalatainak fényében [Once more about the "system paradigm". Clairvoyance and supplements in light of the experiences of the post-socialist region]. Közgazdasági Szemle, Vol. 63, No. 10, 1074-1119, https://doi.org/10.18414/ksz.2016.10.1074.

Kovács, Á. (2017): Rule-Based Budgeting: The Road to Budget Stability: The Hungarian Solution. Polgári Szemle, Vol. 13, Special Issue, 39-63, https://doi.org/10.24307/psz.2017.0304.

Kovács, L. (2013): A devizahitelek háttere [Background to FX loans]. Hitelintézeti Szemle/Financial and Economic Review, Vol. 12, No. 3, 183-193.

Köves, A. (1995): Fordulópont a magyar gazdaságpolitikában? [Breakthrough in Hungarian economic policy?]. Társadalmi Szemle, Vol. 50, No. 8-9, 37-43.

Leeper, E. (1991): Equilibria Under 'Active' and 'Passive' Monetary and Fiscal Policies. Journal of Monetary Economics, Vol. 27, No. 1, 129-147, https://doi.org/10.1016/0304-3932(91)90007-B.

Lentner, Cs. (2013): Közpénzügyek és államháztartástan [Public finances and the study of the general government]. Nemzeti Közszolgálati és Tankönyvkiadó, Budapest.

Lentner, Cs. (2015): The Structural Outline of the Development and Consolidation of Retail Currency Lending. Public Finance Quarterly, Vol. 60, No. 3, 297-311.

Lentner, Cs. (2018): Excerpts on New Hungarian State Finances from Legal, Economic and International Aspects. Pravni Vjesnik, Vol. 34, No. 2, 9-25.

Lentner, Cs. and Hegedús, Sz. (2019): Local Self-Governments in Hungary: Recent Changes through Central European Lenses. Central European Public Administration Review, Vol. 17, No. 2, 51-72, https://doi. org/10.17573/cepar.2019.2.03.

Lentner, Cs. (2020): East of Europe, West of Asia. L'Harmattan, Paris, (5th chapter).

Losoncz, M. (2010): A globális pénzügyi válság és az Európai Unió [The global financial crisis and the European Union]. Pénzügyi Szemle, Vol. 55, No. 4, 765-780. 


\section{Csaba Lentner: Variations on Crisis Management - Through Examples...}

Losoncz, M. and G. Tóth, Cs. (2020): Government Debt Reduction in the Old EU Member States: Is This Time Different? Financial and Economic Review, Vol. 19, No. 2, 28-54, https://doi.org/10.33893/ fer.19.2.2854.

Matolcsy, Gy. (2002): Élő emlékeink. A Széchenyi Terv világa [Our living memories. The world of the Széchenyi Plan]. Heti Válasz Kiadó, Budapest.

Matolcsy, Gy. (2008): Éllovasból sereghajtó. Elveszett évek krónikája [From the vanguard to bringing up the rear. A chronicle of lost years]. Éghajlat Kiadó, Budapest.

Matolcsy, Gy. (2015): Egyensúly és növekedés [Balance and growth]. Kairosz Kiadó, Budapest.

Matolcsy, Gy. and Palotai, D. (2019): Hungary Is on the Path to Convergence. Financial and Economic Review, Vol. 18, No. 3, 5-28, https://doi.org/10.33893/fer.18.3.528.

Mihályi, P. (2014): Mérlegen a rendszerváltás 25 éve [Assessment of the 25 years since the change of regime]. Közgazdasági Szemle, Vol. 61, No. 7-8, 898-922.

Neményi, J. (2009): A monetáris politika szerepe Magyarországon a pénzügyi válság kezelésében [The role of monetary policy in managing the financial crisis in Hungary]. Közgazdasági Szemle, Vol. 56, No. 5, 393-421.

Neményi, J. (2011): A pénzügyi válság hatása központi bankok szabályozására [Impacts of the financial crisis on central banks' regulation] In: Verseny és szabályozás [Competition and regulation]. MTA Közgazdaságtudományi Intézet, Budapest, 167-209.

Orbán, G. and Szapáry, Gy. (2006): Magyar költségvetési politika: quo vadis? [Hungary's fiscal policy: Quo vadis?] Közgazdasági Szemle, Vol. 53, No. 4, 293-309.

Petschnig, M. Z. (1996): Stabilizáció de/konjunktúrában? 1995 gazdasági folyamatainak értékelése [Assessment of the economic developments in 1995]. In: Kurtán, S.; Sándor, P. and Vass, L. (eds.): Magyarország politikai évkönyve 1995 [Hungary’s political almanach]. Demokrácia Kutatások Magyar Központja Alapítvány.

Ramady, M. (2010). The Saudi Arabian Economy. Policies, Achievements, and Challenges. Springer, New York.

Schlett, A. (2017): Közpénzügyi szemléletváltás: Elmozdulási irányok a gazdaságpolitika nagy elosztórendszereiben 2010 után [Directions of shift in the large distribution systems of economic policy]. Új Magyar Közigazgatás, Vol. 10, Special issue, 29-41.

Staviczky, P. (2010): A pénzügyi és gazdasági válság leküzdése érdekében a pénzügyi ágazatra vonatkozó ideiglenes állami támogatási szabályok [Regulations on provisional state support to the financial sector granted to overcome a financial and economic crisis]. In: Állami támogatások joga [The law of state subsidies]. Vol. 2, No. 2, 3-20, Ministry of National Development.

Stumpf, I. (2014): Erốs állam - alkotmányos korlátok [A strong state and constitutional restraints]. Századvég Kiadó, Budapest.

Varga, J. (2017): Reducing the Tax Burden and Whitening the Economy in Hungary after 2010. Public Finance Quarterly, Vol. 62, No. 1, 7-21.

Vukovich, Gy. (1994): Gazdasági folyamatok 1993-ban [Economic processes]. In: Andorka, R.; Kolosi, T. and Vukovich, Gy. (eds.): Társadalmi riport 1994 [Social report]. Tárki, Budapest, 185-217. 